\title{
Собирание фольклора как народная письменность: становление социальной позиции письма в Эстонии 1890-х гг.
}

\section{Катре Кикас}

Отделение фольклористики, Эстонский литературный музей, Эстония

Тартуский университет, кафедра фольклористики, аспирант katreki@folklore.ee

\begin{abstract}
Аннотация: В эстонских книгах по истории XIX век обычно называют «эрой национального возрождения». Важным аспектом этого возрождения была популярная в эпоху Романтизма идея о том, что фольклор отражает "душу народа», что усилило интерес к устной традиции крестьян и побудило различные общества и отдельных людей организовывать кампании по собиранию фольклора. Самая активная фаза собирания фольклора пришлась на 1890-е гг., когда тысячи обычных людей участвовали в кампаниях, организованных Якобом Хуртом (1839-1907) и Маттиасом Йоханном Эйсеном (1857-1934). Результатом этой деятельности стали около 200000 страниц записей, хранящихся сейчас в Эстонском Фольклорном Архиве. В этой статье используется подход, основанный на письменности, и записи собирателей рассматриваются как примеры народной письменности. Особое внимание уделяется различным способам, которые они используют, чтобы позиционировать себя как писателей, и большому спектру мотиваций, которые стоят за этим позиционированием.

Ключевые слова: народная грамотность, практики грамотности, собирание фольклора, Эстония, XIX век, формирование нации
\end{abstract}


Сторонники «идеологической модели» письменности подчёркивают, что письмо и чтение всегда укоренены в социальном и идеологическом контексте, и «когда бы люди ни участвовали в событии, связанном с письменностью, они делают это с социальной позиции» (Sheridan \& Street \& Bloom 2000:4). В этой статье я представлю точку зрения, основанную на письменности в кампаниях по сбору фольклора в Эстонии 1890-х гг., и расскажу, как парадигмы сбора фольклора повлияли на становление социальной позиции, обусловившей письмо участников кампании. Я буду рассматривать собирание фольклора в этот период как «событие письменности» и исследовать «письменные практики» участников. Первый из этих терминов определяется как «деятельность, в которой определённую играет роль письменность» (Barton \& Hamilton 2003: 7), второй - «общекультурные способы использования письменного языка. [---] [О]ни также включают в себя ценности, привычки, чувства и социальные отношения», связанные с использованием письменности (там же: 6).

В этом фокусе заложен эвристический подход: ни одно событие не связано исключительно с письменностью, всегда существуют и другие аспекты. Тем не менее, я всё же утверждаю, что термин «событие письменности» помогает подчеркнуть аспекты, которые до этого оставались незамеченными. Достаточно парадоксально, что, хотя фольклорные манускрипты ценятся как часть эстонского национального наследия, практики тех, кто собирал их, остаются в забвении; в ранних исследованиях про индивидов вспоминали только тогда, когда поднимался вопрос об аутентичности собранных материалов. Учитывая этот аспект, я соглашаюсь с Кати Миккола, что «ценность «нежелательных" объектов состоит в кривых углах, которые они добавляют к идее о том, что прошлое создавалось в соответствии с архивными принципами» (2013: 155): материалы, названные неаутентичными ранними исследователями, могут стать ценными источниками, если поставить другие исследовательские вопросы.

Хотя собирание фольклора как событие письменности может казаться достаточно гомогенным явлением - сфера письменности со своими нормами и стандартами чётко выделяется среди других сфер - эта гомогенность может быть применима к профессиональным фольклористам, которые достигли определённого консенсуса, но не к собирателям, не принадлежащим 
к профрессиональной среде. Этих собирателей обычно называют местными или непрофессиональными, или самоучками, но я фрокусируюсь на них как на представителях «народной письменности» ${ }^{1}$. Народная письменность (или письмо низов) включает практики письменности, которые возникают за пределами институтов, предназначенных для распространения письменности, или которые ре(де)контекстуализируют практики письменности доминирующих институтов, адаптируя их к повседневным нуждам обычных людей. Поскольку этот феномен достаточно вариативен и зависит от контекста, его определение часто содержит негативные коннотации: подчёркивается отсутствие последовательности в письме, и невидимость и маргинальность представителей этих практик. С другой стороны, Иоганн Фабиан отметил, что кажущаяся непоследовательность может быть интерпретирована как знак свободы в использовании языка, которая есть у участника дискурсивного сообщества; он подчёркивает, что эти тексты нужно слушать, а не смотреть (Fabian 2001: 65-66). Карин Барбер указала, что так как эти писатели довольно свободно комбинируют практики из разных сфер, эти записи помогают переосмыслить строгое противопоставление между устным и письменным, доминантным и периферийным, частным и общественным способом коммуникации (Barber 2006; 2007: 207). Народные писатели часто рефлексируют о своей писательской деятельности, уделяя довольно много места обсуждению своих чувств по поводу литературных явлений (Barton \& Hamilton 2003); довольно часто важным аспектом этой деятельности является их надежда, что их социальный статус можно будет изменить путём создания литературной персоны (Barber 2006, 2007).

Можно по-разному применить идею народной письменности к собиранию фольклора. Во-первых, можно посмотреть на практики письменности, присутствующие в самом собранном материале (например, значение книг в сказках). Во-вторых, интерпретировать ситуацию собирания фольклора как стык разных практик письменности: это ситуация, когда современные идеи собирателей сталкиваются с укоренившейся религиозной письменностью их информантов. В-третьих - этот аспект я и собираюсь исследовать - это оценить практики письменности собирателей в контексте современной им общественной 
литературной сферы и узнать о возможностях проникновения в эту сферу, которые предоставляла им парадигма собирания фольклора. Говоря о их деятельности в категориях создания социальной позиции благодаря письму, я подчёркиваю коммуникативную сторону кампаний: это была не только возможность использовать своё умение писать, но и шанс создать социальные контакты и установить связи с единомышленниками - считать себя участником довольно нового вида социальных отношений.

\section{Эстония в XIX в.}

XIX век называют «периодом национального возрождения» в Эстонии ${ }^{2}$, но этому процессу предшествовали довольно значительные социально-экономические изменения. Изменение, которое в наибольшей степени затронуло эстоноязычные низшие классы, - это отмена крепостного права (1816 г. - в Эстляндской губернии, 1819 г. - в Лифляндской губернии), и предоставление права покупки земли (1849 г. - в Лифляндской губернии, 1856 г. - в Эстляндской губернии), что означало экономическую независимость. Активный всплеск национальных идей у эстонцев обычно относят к 1860-м гг.; он проявился в создании различных обществ, становлении регулярных газет и сопутствующем формировании эстонской публичной сферы (Эа Янсон связывает это с определённой полемикой, которая происходила в газетах в 1870-1871 гг., Jansen 2004: 82-83).

Закон об отмене крепостного права также гласил, что землевладельцы должны создать школы для крестьянских детей. Сеть деревенских школ практически полностью сформировалась к 1850-м гг. в Лифолндской губернии и к 1870-м гг. в Эстляндской губернии. Обучение в школе начиналось с 10 лет и длилось 3 года (после чего было возможно продолжать обучение в приходской школе). В первой половине XIX в. преподавали только чтение, Закон Божий и церковное пение, но к середине века к этому добавили письмо, счёт и чтение Библии, в 1870-х гг. географию и русский язык. В начале XIX в. процент грамотных людей среди эстонцев составлял около 45-50\% (Liivaku 1995: 40), а согласно переписи 1897 г., 77\% населения умели писать и $91 \%$ читать (там же: 86 ). 
Последние десятилетия XIX вв. (изучаемый мной период) характеризовались русификацией, т.е. попытками имперских властей более полно интегрировать губернии Прибалтийского края с остальными частями страны (этот процесс начался в середине 1880-х гг., но самыми сложными годами были 1887-1894 гг.). Это проявлялось в использовании русского языка в государственных учреждениях (до этого в основном использовался немецкий), ужесточении цензуры, русскоязычных школах (с 1885 г. только в первых двух классах сельской школы преподавание велось частично на эстонском) и русскоязычном суде (с 1889 г.). Историки отмечают, что русификация была не очень успешной, так как местное русскоязычное меньшинство было слишком мало, чтобы привнести значительные изменения, а знание русского языка школьными учителями было недостаточным для того, чтобы обеспечить его исключительное использование в школах ${ }^{3}$. Тем не менее, как свидетельствуют газеты (и письма собирателей фольклора), люди того времени считали последнее десятилетие XIX в. временем стагнации и затухания национального энтузиазма. В то же время многие из них отмечали два основных стимула, противостоящих стагнации: подъём движения трезвости и кампании по собиранию фольклора.

\section{Кампании по собиранию фольклора в 1890-х гг.}

Важным аспектом «национального возрождения» была популярная в эпоху Романтизма идея (Гердера) о фольклоре как зеркале «души нации», что повысило интерес к устной традиции крестьян и привело к тому, что различные общества и отдельные люди начали организовывать кампании по собиранию фольклора. Первыми проявили интерес к эстонскому фольклору балто-немецкие эстофилы, чьи идеи были хорошо сформулированы в цитате Шульца-Бертрама в 1839 г.: «Дайте народу эпос и историю, и битва выиграна!» (1959: 97). Такие же чувства характеризуют отношение первого поколения эстонских интеллектуалов к фольклору; им удалось напечатать эпос «Калевипоэг» (составленный или написанный Ф. Р. Крейцвальдом, последнее издание на русском языке Крейцвальд 1979). В 1871 г. было образовано Эстонское общество писателей (Eesti Kirjameeste 
Selts), которое провозгласило организацию собирания фольклора одной из своих основных целей и успешно создало достаточно обширную сеть собирателей, состоящую в основном из школьных учителей и священнослужителей (Mälk 1963).

В своём исследовании я уделяю основное внимание периоду примерно 1887-1897 гг., который можно назвать наиболее активной фразой собирания фольклора, или как минимум периодом максимального вовлечения участников: около двух тысяч человек ${ }^{4}$. Важно отметить, что собирание фольклора в эти годы было не институцианализировано 5 - его организовывали разные люди, которые привлекали газеты к распространению информации о своих интересах. Сначала печаталась статья, объясняющая важность фольклора и то, что именно и как нужно собирать. Потом поддерживались связь с собирателями посредством отчётов о полученных материалах.

Также необходимо иметь в виду, что газеты в этой связи выполняли много ролей. Разумеется, они служили средством распространения информации, но так как газеты были также рупором национальных идей, кампании были заметны в этом контексте. Во-вторых, кроме передачи информации о кампаниях по собиранию, газеты взаимодействовали с фольклором и другими способами: они публиковали фольклорные тексты (местные и переводы иностранных источников), интерпретации некоторых сказок или обычаев, полевые рассказы собирателей, литературные произведения, включающие в себя или развивающие фольклорные мотивы, рецензии на опубликованные коллекции народных сказок (обычно считавшиеся ценным материалом для чтения) и реальные истории из современной жизни о последствиях суеверий. Поскольку всё это публиковалось бок о бок с информацией о кампаниях, довольно очевидно, что это влияло на то, как собиратели интерпретировали и оценивали определённые жанры или темы. И в-третьих, во всех газетах была специальная колонка местных новостей, которая в основном состояла из писем, присланных местными жителями: это означает, что читатели газеты привыкли считать себя активными участниками процесса; этот опыт мог повлиять на их решение попробовать себя также в собирании фольклора ${ }^{6}$.

Моё исследование фокусируется главным образом на кампаниях, организованных двумя пасторами - Якобом Хуртом 
(1839-1907) и Маттиасом Йоханном Эйсеном (1857-1934) - чьи сети собирателей были самыми обширными, а кампании длились дольше всего ${ }^{7}$. Результатом их деятельности стали примерно 200,000 страниц записей, хранящихся сейчас в Эстонском Фольклорном Архиве.

И Хурт, и Эйсен были хорошо известными общественными деятелями, что безусловно способствовало успеху их кампаний. Хотя они оба приветствовали любой вид фольклорных источников, их сферы интересов слегка различались: Хурт предпочитал рунические песни, в то время как Эйсен делал упор на нарративный материал (особенно легенды). Кроме того, Хурт подчёркивал введение коллекций в научный оборот, в то время как Эйсен больше заботился о немедленной публикации, т.е. предоставлении материала для чтения растущей эстоноязычной аудитории. Последнему аспекту открыто противостоял Хурт, который опасался, что немедленные публикации влияют на последующий сбор материала. Обвинения Хурта подхватили издатели разных газет и в 1893 г. имели место активные обсуждения целей публикации фольклорных текстов. Таким образом, неинституцианализированное собирание фольклора в этот период было спорной и даже противоречивой сферой деятельности ${ }^{8}$.

Люди, которые отвечали на призывы Хурта и Эйсена, имели разное происхождение. Большинство были мужчинами, но были также активные женщины. Были представлены разные возрастные группы (начиная с 12-летних школьников). Согласно Эа Янсену, 42\% участников были сельскими учителями и $32,4 \%$ фермерами, но кроме этих двух больших групп были также представители интеллигенции (студенты университетов, учёные, пасторы, писатели), портные, различные чиновники, слуги и представители других cdpep (Jansen 2004: 19-35) ${ }^{9}$. Однако важно понимать, что эта статистика не отражает особых вкладов этих групп: тремя наиболее активными собирателями этого времени были портные Яан Сандра (родился в 1862 г.), Ганс Антон Шульц (родился в 1866 г.) и лесник и журналист Яак Сыггель (родился в 1871 г.) (Шульц сотрудничал с Хуртом, Сыггель и Сандра собирали фольклор и для Хурта, и для Эйсена). С другой стороны, интеллигенция обычно участвовала в одной или двух кампания по сбору (исключение составляют 
студенты университета, которые получали стипендии на свои полевые исследования).

Мотивации собирателей были, разумеется, столь же различны, как и их происхождение. Сельских учителей и фермеров можно назвать главной целевой аудиторией, к которой напрямую обращались Хурт и Эйсен. К учителям обычно обращались весной перед началом летних каникул, а к фрермерам осенью после завершения работ в поле: в обоих случаях подчёркивалось, что долг человека - провести свободное время за собиранием фольклора. В то время как эти сезонные и ориентированные на определённые группы призывы, несомненно, повлияли на активное участие этих целевых групп, были и разные другие мотивирующие фракторы, зависящие от определённых условий. Например, собиратели с какими-либо физическими ограничениями поневоле имели много свободного времени и приветствовали собирание фольклора как подобающее времяпрепровождение ${ }^{10}$; собиратели, которые не жили в своём родном приходе (они переехали в город, временно находятся в армии или живут за пределами Прибалтийских губерний) обнаружили, что вспоминание и записывание фольклора даёт им возможность поддерживать связь с местом своего рождения; а юные школьники рассматривали собирание фольклора как способ поучаствовать во взрослых делах ${ }^{11}$.

\section{Становление социальной позиции(-ий) письма}

Какой тип письма представляет собой собирание фольклора? Главное правило - это «записывать в точности так, как это говорится народом». Это требование выглядит довольно простым, но в действительности ему может быть довольно сложно следовать. Даже вопрос о том, где начинается или заканчивается история, не столь прямолинеен: есть собиратели, которые стараются представить разные истории как независимые единицы (с названием и нумерацией), а другие записывают похожие истории, вплетая одну в другую. Ещё одно правило - это «чётко разделять слова собирателей и информантов» - также достигается разными собирателями по-разному и в разной степени. Например, некоторые 


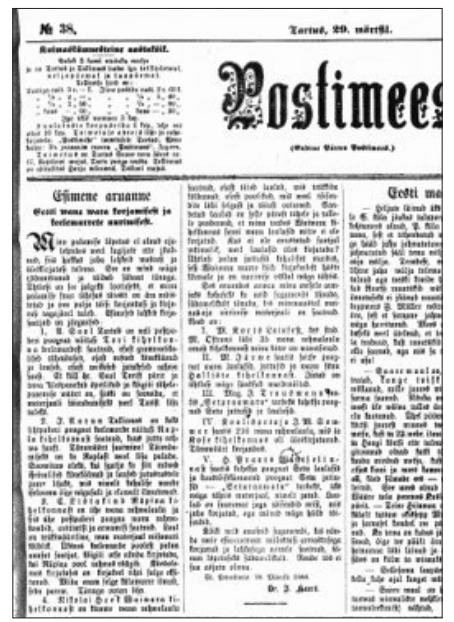

Отрывок из первого отчёта о собирании фольклора Якоба Хурта. Опубликован в газете «Postimees» 29 марта 1888 г.

упоминают, что названия дали они сами, но большинство об этом умалчивают, хотя достаточно очевидно, что названия не являются частью устной культуры. Некоторые сказки, в которых упоминаются реально существующие названия мест, начинаются с объяснения местонахождения этих мест, и, хотя кажется, что это дополнение собирателя делает историю более понятной неместному читателю, это часто не указывается.

Двусмысленности, заложенные в основных правилах, можно увидеть в неопределённом тоне собирателей, впервые связывающихся с Хуртом или Эйсеном. Они не уверены в качестве записанного материала и правильности их методик записи. В то же время они, считая данностью существование чётких правил, объясняют свои возможные отклонения от них недостатком (или полным отсутствием) образования. Они также подчёркивают, что они участвуют («вторгаются в сдреру образованных людей») только потому, что «учёные мужи» их края игнорируют кампанию (вывод, который они сделали вследствие отсутствия их местности в отчётах о сборе фольклора). Собиратель Юрий Пуурманн писал Хурту в 1888 г.: 
Каждый раз, когда я получаю «Postimees» [одну из крупнейших газет - К. К.], я читаю, как много кто-то прислал фольклора, что приносит мне большое удовольствие. Мой взгляд всегда цепляется за то, сколько прислали из прихода Вайке-Марья, но увы, это всегда оказывается немного. Это заставило меня задуматься. Пока ждёшь, когда писатели, местные директора и писцы засядут за эту патриотическую работу - безземельные крестьяне должны попытаться сами взять в руки перо, чтобы записать то, что знают ${ }^{12}$.

Один из возможных способов, который они использовали, чтобы преодолеть свою застенчивость, - это подчёркивание своих национальных чувств, используя фрразы и метафоры, которые употребляли Хурт и Эйсен в своих работах. Например, собирание часто называют «строительством памятника нации» или «выкапыванием скрытых народных богатств» ${ }^{13}$. Однако обращает на себя внимание тот факт, что в письмах собирателей эти идеалы находятся бок о бок с более приземлёнными материями. Так как Эйсен имел обыкновение награждать собирателей книгами (они были довольно разнообразными, кроме сборников фольклора были также романы, пьесы, поэзия, история и т.д.), некоторые высылали ему списки наиболее интересных им книг. Некоторые просили Хурта или Эйсена написать речь для произнесения на собрании местного движения трезвости в надежде, что это сделает движение более популярным в их округе. Довольно большое количество писем содержит просьбу помочь в поиске лучшей работы (в Санкт-Петербурге или Кронштадте ${ }^{14}$ - просьба, довольно резко диссонирующая с парадигмой собирания фольклора, так как переезд в город давал меньше возможностей для собирания); а Ганс Кару (рождённый в 1868 г.), чьи ноги были парализованы, попросил у Хурта новое инвалидное кресло.

Хотя и не все просьбы были удовлетворены, довольно многие собиратели получили помощь. Ханс Кару получил инвалидное кресло; некоторые получили советы по поиску новой работы и финансовую поддержку для обучения в городе. Эти примеры показывают, что письмо в рамках парадигмы собирания фольклора могло использоваться как социальный ресурс для решения проблем. Собирание было добровольной деятельностью, но можно было относится к нему и как к услуге, за которую нужно отплатить. 


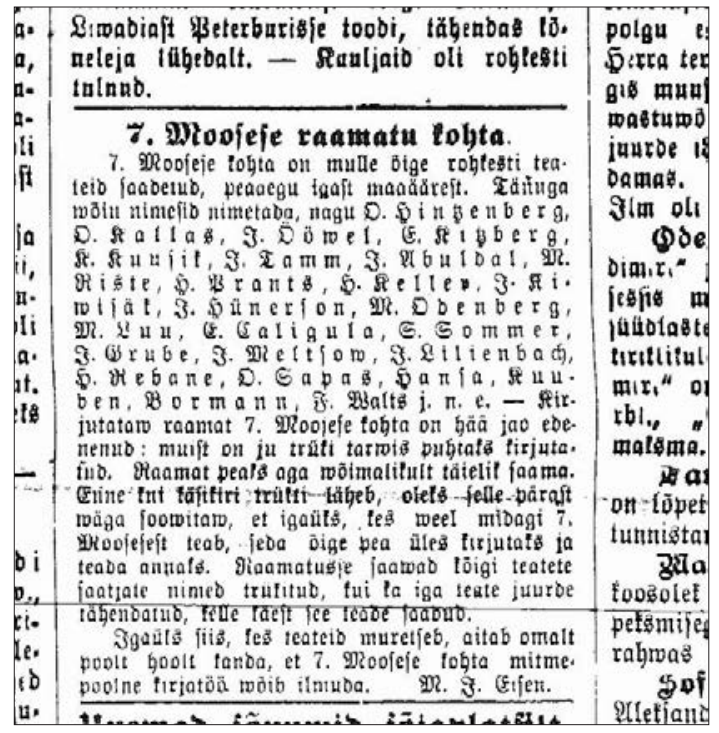

М. Й. Эйсен часто публиковал призывы к собиранию фольклора определённой тематики. В этом тексте акцент сделан на народных сказках о Шестой и Седьмой книгах Моисея. Кроме благодарности собирателям, он также описывает текущий статус готовящейся публикации. Опубликовано в газете «Sakala» 9 ноября 1894 г.

Ещё одним источником неопределённости и сомнения была позиция местного населения. В то время как на национальном уровне собиратели фольклора считались представителями своей местности, на местном уровне собирание фольклора не всегда вызывало уважение к тому, кто его записывал. Скорее, их считали чудаковатыми, наполовину чужими. Для старшего поколения (среди которого они собирали материал) грамотность была так тесно связана с религией, что идея записывать мирские сказки казалась кощунственной ${ }^{15}$. Более молодое поколение считало их деятельность пустой тратой времени (они могли делать записи только в свободное время) и денег (на бумагу и чернила) и пропагандой суеверий (такие обвинения поступали также в адрес Хурта со стороны его коллег) или тщеславным желанием увидеть своё имя в газете. Так, одна из наиболее активных женщин-собирательниц Хелене Маасен (родилась в 1869 г.) писала Эйсену в 1892 г.: 


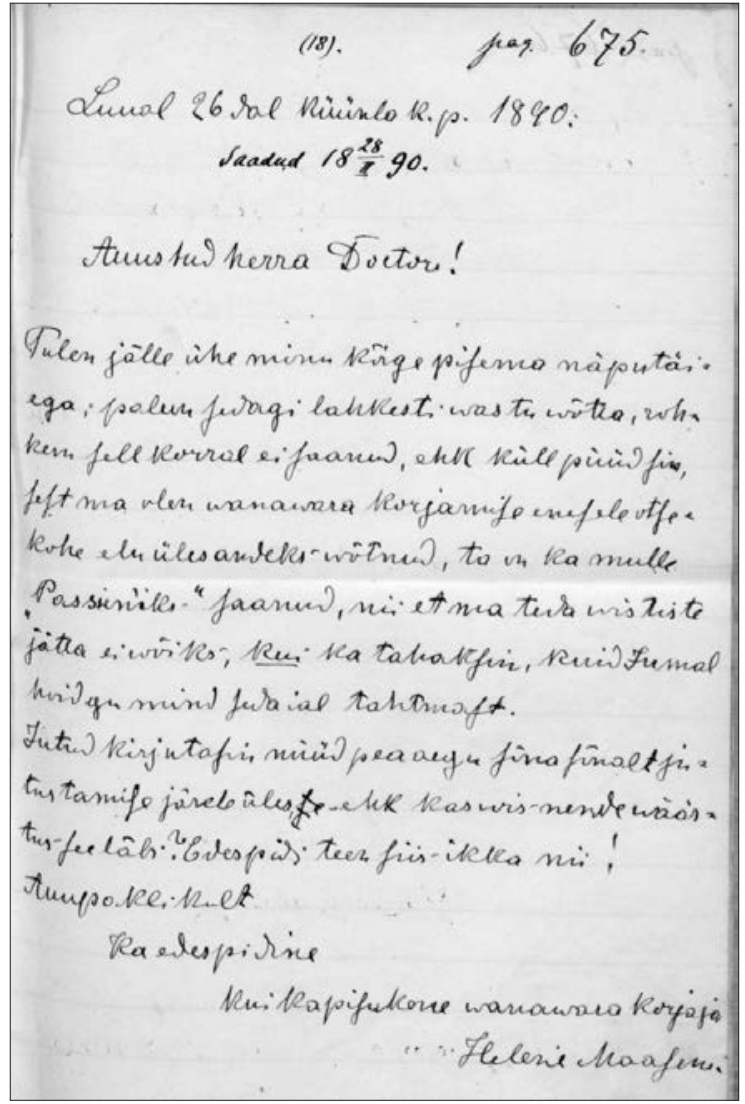

Письмо Хелен Маасен Якобу Хурту, в котором она утверждает, что собирание фольклора для неё- это «страсть всей жизни» (Н III 8, 675).

Правду сказать, я ещё не привыкла к насмешкам, и я очень смущаюсь, когда, прочитав моё имя в последнем отчёте о собирании, злые люди насмехаются надо мной, что я сую повсюду свой нос по причине и без, хотя поистине перо - мой лучший спутник и моя единственная услада в моей тоскливой невзрачной жизни в поздние ночные часы. Из-за этого я от всего сердца умоляю Вас не писать моё полное имя рядом с моими материалами в газетных отчётах о собирании ${ }^{16}$. 
Но кроме жалоб на проблемы Хурту или Эйсену, собиратели также активно пытаются переломить ситуацию, например, искать единомышленников, которые, как и они, считают собирание фольклора важным делом. Некоторые собиратели присылали Хурту или Эйсену «побудительные кличи»: тексты, где они обращаются к местным людям и объясняют важность этого, чтобы их приход не отставал от соседних; они ожидали, что Хурт и Эйсен включат эти тексты в свои отчёты о сборе фрольклора. Другие начинают открытую агитацию: например, Хелене Маасен пишет в 1890 г., что она одалживает книги только тем, кто взамен будет собирать фольклор ${ }^{17}$. Хотя кажется, что эти призывы не всегда были успешны, всё же часть собирателей работают в парах и даже в более обширных местных сетях. По таким начинаниям мы видим, что эти люди не считали письмо непременно уединённым занятием - в противоположность этому современному мифу, они интерпретировали свою деятельность как возможность создать новые отношения.

Существование этих местных сетей действительно является уместным ответом на вопрос, давала ли парадигма собирания фольклора возможность создать социальную позицию для своего письма. Однако это была не единственная возможность; кроме того, были собиратели фольклора, которые пытались использовать парадигму собирания фольклора, чтобы создать для себя действительно публичную позицию письма. Например, некоторые собиратели пишут о своём намерении опубликовать сборник местных сказок. Другие присылают рукописи со своими собственными творческими записями и просят прокомментировать их и дать совет по дальнейшей публикации. Последние примеры в основном встречаются в коллекции Эйсена, который помимо комментирования даже давал активным собирателям возможность предложить своё художественное произведение для редактируемого им календаря. Тот фракт, что Эйсен сознательно использовал желание собирателей стать известными писателями для продвижения своей инициативы, также подчёркивается в объяснении собирателя Яана Тамма Хурту, почему он сотрудничает с Эйсеном:

Я действительно написал несколько своих рассказов и стихов, и наконец подумал, что они могут сгодиться для того, чтобы стать литературой. Но чтобы эти рукописи изучил эксперт, я попросил известного эстонского писателя и учёного Эйсена любезно 


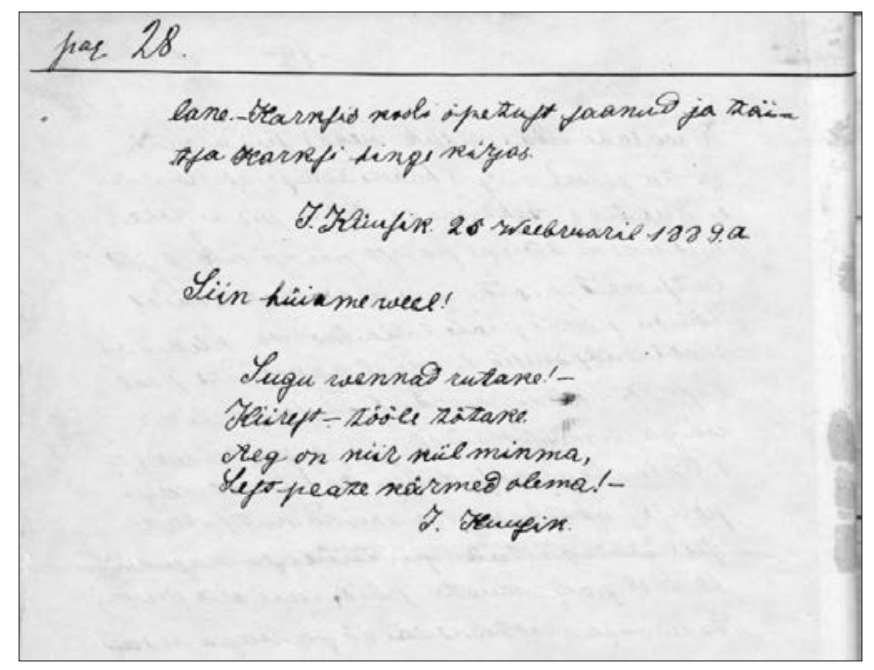

Многие собиратели писали «побудительные призывы», чтобы активизировать деятельность собирателей на местах. Здесь представлен редкий пример призыва в стихах, написанный Юханом Куусиком в 1889 г. (H II 23, 28).

выполнить мою просьбу. Господин Эйсен пообещал сделать это [...], но сообщил мне [...], что он также хотел бы получить какиенибудь старые сказки. Так мне ничего не оставалось делать, как собрать и отправить немного старых сказок. Потому что это был мой долг отплатить за работу... ${ }^{18}$

Собиратели, которые просят помощи в публикации, используют один контекст письма для становления своей позиции в другом контексте письма. В некоторых случаях, однако, мы видим определённое гибридное позиционирование: писатели начинают заниматься собиранием фольклора как расширением сореры общественной литературы и присылают свои интерпретации текущих событий, ответы на газетные статьи или отзывы о прочитанных ими книгах ${ }^{19}$. Они не просят, чтобы их опубликовали, но их записи определённо структурированы по модели, которую они видели в СМИ; в некоторых случаях эти тексты даже адресованы не лично Хурту или Эйсену, а анонимным читателям. Гибридное позиционирование может также включать идиосинкразические фольклорные сборники: тексты, 
где собранный фрольклор переплетается с литературными мотивами, национальной мифологией, Библией и творчеством самих собирателей (всё это оформлено как вышедшее «из уст народа» и даже указаны имена информантов).

Два довольно интересных примера такого типа - это Ганс Антон Шульц (родился в 1866 г.) и Мярт Сиипсен (родился в 1842 г. $)^{20}$. В своих записях Шульц разрабатывает национальную романтическую мифологию, но он также присылает Хурту отзывы о разных публикациях фольклора; Сиипсен отправляет Эйсену статьи, которые отказались взять газеты, и размышления на религиозную тему. Интересная черта этих писателей состоит в том, что позиция письма, которую они пытаются себе создать, уже устарела. Их идеи о фольклоре, истории и обществе напоминают идеи ранних эстоноязычных интеллигентов, которые были активны за 50 лет до этого - но в 1890-х гг. идеи этих деятелей уже подвергло критике новое поколение. Шульц и Сиипсен посвящают довольно значительную часть своих записей противостоянию этим критикам. Такой анахронизм, заложенный в их идеях, мог быть одной из причин, почему они были вынуждены использовать парадигму собирания фольклора, чтобы оформить в ее рамках все свои записи: для них не было места в настоящем публичном пространстве. Однако, несмотря на этот анахронизм, позиции письма, к которым они стремятся, по природе своей социальны. Даже если они во многом отличались от других участников, они стояли бок о бок в отчётах о сборе фольклора, что определённым образом нивелировало все различия и обеспечивало им место в сообществе собирателей фольклора.

\section{Заключение}

Цель кампаний по собиранию фольклора - приобрести знание о прошлом, и впоследствии рукописи в основном использовались в соответствии с этой изначальной целью - для изучения культуры әстонских крестьян. В последние годы, фокус архивных исследований в фольклористике переместился с содержания к вопросу о месте этих рукописей в производстве фольклористических знаний. В этой статье я постаралась изучить одно из 
ранее достаточно незаметных или скрытых звеньев в этой цепи производства знаний - практики письменности собирателей.

Достаточно интересно, что, хотя участие в собирании фольклора могло помочь этим людям приобрести уверенность в себе в качестве писателей и найти позицию, с которой они могли писать, эта связь не была автоматической. Многие столкнулись с недоумением со стороны членов семьи и соседей; что означает, что они в первую очередь должны были убедить других в ценности позиции, к которой они стремились. Поэтому довольно удивительно было узнать, что многие собиратели работали в парах: некоторые смогли создать даже более плотные местные сети, другие старались наладить контакт с единомышленниками посредством написания «побудительных призывов» для публикации в фольклорных отчётах.

Мотивации для участия в кампаниях по сбору фольклора были достаточно различными, как и происхождение самих собирателей; также вероятно, что у большинства людей было несколько мотиваций и основные мотивации отдельных людей менялись с течением времени. Так как большинство писателей задействуют выражения и метафоры, которые используются для того, чтобы связать собирание фольклора с более широким национальным движением, кажется, что участие в собирании фольклора было удобным способом, чтобы сделать достаточно абстрактную (или, используя термин Бенедикта Андерсена, «воображаемую», см. Anderson 2006: 6-7) идею «нации» более реальной и близкой. Однако кроме этого многие писатели используют парадигму собирания фрольклора как социальный ресурс для решения специфических проблем или для вхождения в публичное литературное пространство. Некоторые собиратели предпочитают создать себе несколько позиций письма, разделяя свои фольклорные сборники и литературные произведения. Для них парадигма собирания фольклора является особого рода пространством для экспериментирования с разными способами позиционирования себя как писателей, прежде чем выбрать подходящий способ для вхождения в публичную сферу. Другие создают гибридную позицию и пытаются раздвинуть границы собирания фольклора, чтобы включить туда различные свои записи - для них это являлось как бы продолжением общественного пространства. 


\section{Выражение благодарности}

Работа над статьёй осуществлена при поддержке Министерства образования и науки Эстонии (институциональный исследовательский грант IUT 22-5 и EKKM14-389) и Фонда регионального развития ЕС (Центр компетенции по Эстонским исследованиям CEES - TK 145).

\section{Примечания}

1 Мне известно, что термин «народная письменность» имеет собственное значение в русскоязычной фольклористике (Николаев 2010; Моисеева \& Рожкова \& Лосеева \& Дерябина 2015), но тут я использую его в качестве эквивалента термина "vernacular literacy», достаточно широко использующегося в англоязычной литературе. Но важно помнить, что есть довольно много других терминов, описывающих эту концепцию. Так, кроме «vernacular literacy» (Barton \& Hamilton 2003; Street 2000), можно встретить также «ежедневная письменность» («everyday literacy») (Barton \& Hamilton 2003; Barber 2006, 2007), «местная письменность» («local literacy») (Barton, Hamilton 2003), «письменность из сундука» «tin-trunk literacy» (Barber 2006, 2007), «письменность низов" ("grassroots literacy») (Fabian 2001), «письменные практики обычных людей» («the literacy practices of ordinary people») (Sheridan, Street, Bloom 2000) и «исконная письменность» («indigenous literacy») (van Toorn 2006). Термин Карин Барбер «письменность из сундука» кажется мне особенно интересным, т.к. это отличный пример термина с отсылкой к конкретной ситуации: в африканских колониях люди использовали сундуки (спрятанные под своими кроватями) для хранения разного рода письменных материалов (документов, налоговых накладных, дневников, писем, некрологов, брошюр и т.д.), и поэтому термин «письменность из сундука» отражает практики письменности людей, которые их создали (Barber 2006: ix). Ещё одна причина отдать предпочтение термину «народная письменность» - это возможность связать его с термином «народная теория»: идеей о том, что теоретизируют не только учёные, но и обычные люди имеют теоретический подход к своей повседневной жизни (Briggs 2008; McLauglin 1998). 
2 Я признаю, что говорить об «Эстонии» в этом контексте является анахронизмом: в XIX в. территория современной Эстонии была разделена между двумя провинциями Российской империи: Эстляндской губернией (северная Эстония с центром в Таллинне) и Лифляндской губернией (южная Эстония и современная северная Латвия, с политическим центром в Риге и интеллектуальным центром в Тарту). Местная власть была разделена между местной элитой из балтийских немцев и русскими, эстоноязычное большинство было в основном представлено сельскими жителями; если крестьянину удавалось улучшить своё социально-экономическое положение, это означало германизацию (или русификацию). Этноним «эстонец» (для обозначения носителя эстонского языка, а не обитателя Эстляндской губернии) стал популярен примерно в середине XIX в.; до этого использовался термин «таarahvas» (народ этой земли).

3 Скорее всего главной мишенью русификации были не әстонцы, а местные немцы, которые в результате потеряли некоторые из своих привилегий (детальное описание их реакции можно найти в Piirimäe 2012: 95-102).

4 Это примерное число. Нам известно, что у Хурта было как минимум 1400 корреспондентов, но никто не считал корреспондентов Эйсена. Возможно, его сеть была меньше, и было значительное наложение двух сетей друг на друга, поэтому цифра в 2000 человек кажется вероятной.

5 Эстонское общество писателей (Eesti Kirjameeste Selts), которое координировало собирание фольклора в предыдущие десятилетия, было закрыто цензурными органами в 1893 г., но ещё до этого оно утратило свою центральную роль из-за внутренних проблем. Эстонский фольклорный архив был основан в 1927 г.

6 Бенедикт Андерсон утверждал, что газеты играют огромную роль в «воображении» нации, но любопытно, что он говорит только о позиции читателей (2006: 25, 32-36). В случае Эстонии возможность поучаствовать в качестве писателя была так же важна, как и чтение газет. На это указывает и Карин Барбер (Barber 2007: 141-142).

7 Кроме этих двух человек, были и другие, сконцентрировавшиеся на каком-либо более специфическом аспекте народной культуры: как студент-медик Михкель Остров собирал информацию о традиционной медицине; редактор газеты и композитор Карл Аугуст Херманн сосредоточился на народных мелодиях; археолог Яан Юнг - на фольклоре, связанном с важными археологическими местами; лингвист (и официальный цензор) Юрий Труусман - на названиях 
мест. Были и дальнейшие кампании, которые могли включать фольклорные нарративы: например, активист движения трезвости Яак Ярв интересовался историями про вред потребления алкоголя.

8 Взвешенный исторический обзор работы обоих собирателей см. у Jaago 2005 and Kuutma 2005. Куутма также обсуждает сходства и различия в их работе. Некоторую информацию о Хурте и Эйсене (и истории эстонской фольклористики) можно также найти в двух русскоязычных публикациях: Калрмэ 1996, Мялк, Вийдалепп 1980.

9 Это статистика основана только на коллекции Хурта. Подобной статистики о коллекции Эйсена нет, но вполне возможно, что она была бы похожей.

10 Это не очень многочисленная подгруппа собирателей; мне известны три таких человека: один с парализованными ногами, один с парализованной рукой и один глухой человек, записывающий по памяти. Однако эта подгруппа очень заметна, так как этих людей часто выделяли в отчётах как настоящих героев.

${ }^{11}$ Есть два типа учеников-собирателей: те, кто собирал фольклор в рамках своих школьных заданий (и эти материалы отправляли Хурту и Эйсену их учителя) и те, для кого участие было их личным решением. Здесь я имею в виду вторую группу.

${ }^{12}$ H III 16, 105/6 Jüri Puurmann (1888).

${ }^{13}$ Очень релевантное обсуждение метафор, используемых для объяснения ценности собирания фольклора, можно найти в Valk 2004.

14 Так как немецкие землевладельцы предпочитали пасторов немецкого происхождения, для эстоноязычных пасторов было сложно найти работу в Прибалтийских губерниях. В результате, довольно много образованных эстонцев были вынуждены искать работу в других частях Российской империи. И Хурт, и Эйсен могут служить примером этого феномена: Хурт жил и работал в Санкт-Петербурге, а Эйсен в Кронштадте. Однако вследствие того, что оба этих города были направлениями эстонской трудовой миграции, у обоих там были эстоноязычные конгрегации.

${ }^{15}$ Собиратели часто утверждали, что их информанты неграмотны, но они определённо владели хотя бы так называемой религиозной грамотностью: «способностью читать знакомые (религиозные) тексты» (Ólafsson 2013: 43). Например, собиратель Ганс Антон Шульц (родился в 1866 г.) обычно называет своих информантов неграмотными, но в попытке объяснить, почему некоторые из записанных им историй напоминают опубликованные Крейцвальдом, он утверждают, что эти 
истории не могут быть взяты из книг, потому что единственные книги, которые есть дома у его информантов, это «Библия» и «Псалтыры» (H II 67, 414/5). Данная идея о том, что религиозная грамотность является знаком неграмотности, созвучна с проведением Бриттом Лильеваллом разграничения между формальной и функциональной грамотностью, согласно которому один из факторов функциональной грамотности это «желание читать «мирские» тексты» (Liljewall 2013: 33).

${ }^{16}$ E 619/20 Helene Maasen (1892).

${ }^{17}$ H III 8, 795/7 Helene Maasen (1890).

${ }^{18}$ EKLA f 43, m 22:27, 1 8/12-8/13 Jaan Tamm (1893).

${ }^{19}$ Моя концепция «расширение сферы общественной литературы» довольно близка с термином Кирсти Салми-Никландер «полу-публичная сфера", который она использует для того, чтобы определить статус рукописных газет. Интересно, что она также подчёркивает, что для некоторых людей, которые участвовали в создании этих газет, они служили «подготовкой к общественной жизни, письму для печатных публикаций и участию в политической деятельности», в то время как для других «полу-публичная сфера и социальное письмо было единственным способом представить свои идеи, мнения и мечты более широкой аудитории» (Salmi-Niklander 2013: 64).

${ }^{20}$ О Шульце см. Kikas 2010, о Сиипсене Kikas 2015.

\section{Архивные источники}

$\mathrm{E}=$ Коллекция фольклора Маттиаса Йоханна Эйсена (хранится в Эстонском Фольклорном Архиве)

H = Коллекция фольклора Якоба Хурта (хранится в Эстонском Фольклорном Архиве)

EKLA, f 43 = Собрание писем, отправленных Якобу Хурту (хранятся в Эстонском культурно-историческом архиве) 


\section{Литература}

Anderson, Benedict 2006. Imagined Communities. Reflections on the Origin and Spread of Nationalism. London, New York: Verso.

Barber, Karin 2006. Introduction: Hidden Innovators in Africa. Karin Barber (ред.). Africa's Hidden Histories. Everyday Literacy and Making the Self. Bloomington and Indianapolis: Indiana University Press, cc. 1-24.

Barber, Karin 2007. The Anthropology of Texts, Persons and Publics. Oral and Written Culture in Africa and Beyond. Cambridge: Cambridge University Press.

Barton, David \& Hamilton, Mary 2003 [1998]. Local Literacies. Reading and Writing in One Community. London, New York: Routledge.

Briggs, Charles L. 2008. Disciplining Folkloristics. Journal of Folklore Research. Grand Theory 45 (1), cc. 91-105.

Fabian, Johannes 2001. Keep Listening: Ethnography and Reading. Anthropology with an Attitude. Critical Essays. Stanford, California: Stanford University Press, cc. 53-69.

Jaago, Tiiu 2005. Jakob Hurt: The Birth of Estonian-language Folklore Research. Kristin Kuutma \& Tiiu Jaago (ред.). Studies in Estonian Folkloristics and Ethnology. A Reader ad Reflexive History. Tartu: University Press, cc. 45-64.

Jansen, Ea 2004. Vaateid eesti rahvusluse sünniaegadesse. Tartu: Ilmamaa.

Калмре, Эда 1996. Эстонский фбольклорный архив. Тарту: Эстонский литературный музей.

Kikas, Katre 2010. Rahvaluulekoguja raamatuid otsimas. Hans Anton Schults. Acta Semiotica Estica VII, cc. 64-101.

Kikas, Katre 2015. Mis kuulsin rahva suust se panin kirja... . Mölder Märt Siipseni kirjalikust pärandist. Velsker, Mart (ред.). Tartu Ülikooli Lõuna-Eesti keele- ja kultuuriuuringute keskuse aastaraamat XIII-XIV. Tartu: Tartu Ülikool, cc. 33-54.

Крейцвальд, Фри́дрих Ре́йнгольд 1979. Калевипоэг. Таллинн: Ээсти раамат. 
Kuutma, Kristin 2005. Matthias Johann Eisen: A Collector and Publisher of Narratives. Kristin Kuutma \& Tiiu Jaago (ред.). Studies in Estonian Folkloristics and Ethnology. A Reader ad Reflexive History. Tartu: University Press, cc. 79-99.

Liivaku, Uno 1995. Eesti raamatu lugu. Monolleö: Jyväskylä.

Liljewall, Britt 2013. Recollections of Reading and Writing. Another Picture of Swedish Literacy. Anna Kuismin \& M. J. Discroll (ред.). White Field, Black Seeds. Nordic Litercy Practices in the Long Nineteenth Century, cc. 30-39.

McLauglin, Thomas 1998. Theory outside the academy: Street smarts and critical theory. Consumption Markets \& Culture 2 (2), cc. 203-231.

Mikkola, Kati 2013. Self-taught Collectors of Folklore and their Challange to Archival Authority. Anna Kuismin \& M. J. Discroll (ред.). White Field, Black Seeds. Nordic Litercy Practices in the Long Nineteenth Century, cc. 146-157.

Моисеева, Светлана Алексеевна \& Рожкова, Татьяна Ивановна \& Лосеева, Ирина Владимировна \& Дерябина, Е. Б. 2015. О войне из войнь:: народная письленность 1941-1945 ге. Магнитогорск: «МГТУ им. Г.И. Носова».

Mälk, Vaina 1963. Eesti Kirjameeste Seltsi osa eesti folkloristika arengus. Tallinn: Eesti Riiklik Kirjastus.

Мяльк, Вайна \& Вийдалепп, Рихард 1980. Сбор и изучение эстонского фольклора. Эстонский фбольклор. Таллин: Ээсти раамат.

Николаев, Олег Рудольфович 2010. Наивная фольклористика: типы, формы, функции. Живая старина 1, сс. 2-5.

Ólafsson, David 2013. Scribal Communities in Iceland. The Case of Sighvatur Grimsson. Anna Kuismin \& M. J. Discroll (ред.) White Field, Black Seeds. Nordic Literacy Practices in the Long Nineteenth Century, cc. 40-49.

Piirimäe, Eva 2012. Humanität versus nationalism as the moral foundation of the Russian Empire: Jegór von Sivers' Herderian cosmopolitanism. Ajalooline ajakiri 1/2, cc. 79-113. 
Salmi-Niklander, Kirsti 2013. Monologic, Dialogic, Collective. The Modes of Writing in Hand-Written Newspapers in 19th- and 20th-century Finland. Anna Kuismin \& M. J. Discroll (ред.). White Field, Black Seeds. Nordic Litercy Practices in the Long Nineteenth Century, cc. $76-88$.

Schultz-Bertram, G. 1959. Vortrag über Kalevipoeg, verlesen in der Sitzung der Gelehrten Estnischen Gesellschaft im Oktober 1893. E. Laugaste \& E. Normann (ред.). Muistendid Kalevipojast. Tallinn: Eesti Riiklik Kirjastus, cc. 95-100.

Sheridan, Dorothy \& Street, Brian \& Bloom, David 2000. Writing Ourselves. Mass-Observation and Literacy Practices. Creskill, New Jersey: Hampton Press, Inc.

Street, Brian 2000. Introduction: the new literacy studies. Brian Street (ред.). Cross-Cultural Approaches to Literacy. Cambridge: Cambridge University Press, cc. 1-21.

Valk, Ülo 2004. On the Discursive Foundations of Estonian Folkloristics: A Farmer's Field of Vision. Ene Kõresaar \& Art Leete (ред.). Everyday Life and Cultural Patterns: International Festschrift for Elle Vunder. Studies in Folk Culture 3. Tartu: Tartu University Press, cc. 265-272.

Van Toorn, Penny 2006. Writing Never Arrives Naked. Early Aboriginal Cultures of Writing in Australia. Canberra: Aboriginal Studies Press. 


\section{Summary}

\section{Folklore Collecting as Vernacular Literacy: Establishing a Social Position for Writing in 1890s Estonia}

\section{Katre Kikas}

Keywords: vernacular literacy, literacy practices, folklore collecting, Estonia, 19th century, nation building

In Estonian history books, the 19th century is usually referred to as 'the era of national awakening'. A significant aspect of this awakening was the Romantic idea of folklore as the mirror image of 'the soul of the nation', which intensified interest in the oral tradition of peasants and prompted various societies as well as individuals to organize collecting campaigns. The most active phase of folklore collecting was in the 1890s when thousands of common people participated in the campaigns initiated by Jakob Hurt (1839-1907) and Matthias Johann Eisen (1857-1934). The result of these activities was approximately 200,000 pages of writings, currently stored in the Estonian Folklore Archives. The article takes the literacy-centred approach to the subject matter, treating the collectors' writing practices as examples of vernacular literacy. The focus is on the variety of ways in which they position themselves as writers and on the diverse range of motivations that can be seen behind these positions. 


\section{МИССИЯ ВЫПОЛНИМА Перспективы изучения фольклора}

http://www.folklore.ee/rl/pubte/ee/sator/sator19/

ISSN 1736-0323

ISBN 978-9949-586-60-8

DOI: $10.7592 /$ Sator.2018.19

Тарту 2018

Редакторы-составители выпуска:

Маре Кыйва \& Татьяна Володина

Редактор серии: Маре Кыйва

Фото: Яак Кикас, 2018 «Осень в Тарту»

Оформление обложки: Лииса Весик

Верстка \& HTML: Диана Кахре

Печатное издание: МИССИЯ ВЫПОЛНИМА:

Перспективы изучения фольклора. SATOR 19. Тарту 2018

Публикация книги осуществлена совместно Эстонским литературным музеем и Центром исследований белорусской культуры, языка и лит ерат уры Националь ной акад емии наук Б еларус и, п ри поддержке Министерства образования и науки Эстонии (IUT 22-5), Фонда регионального развития ЕС (ТK 145, Центр компетенции по Эстонским исследованиям); при поддержке проекта, финансируемого Министерством иностранных дел Эстонии из бюджета по сотрудничеству и развитию, Эстонской Академией Наук и Национальной академии наук Беларуси.

Оформление электронного издания осуществлено при поддержке проекта ЕККМ14-344 “Расширение областей применения и представление эстонского языка, культуры и фольклора в электронных информационных средствах".

() Эстонский литературный музей

(c) Авторы

(с) Яак Кикас 